\title{
Relationship Of Treatment-Seeking Behavior With Maintenance Of Street Child Health In Magetan Regency
}

\author{
Nendya Oktavialia \\ Undergraduate Public Health Study Program with PKIP Specialization, School of Health Sciences
}

(STIKES) Bhakti Husada Mulia Madiun

ARTICLE INFO

Keywords:

Street children, search behavior, health maintenance
E-mail:nendyaokt15@gmail.com

\begin{abstract}
This study aims to determine the behavior of seeking treatment by maintaining the health of street children in the Maospati area of Magetan district. The behavior of seeking treatment for street children in the Maospati area of Magetan Regency in general is that which is often done by self-medicating, namely by buying medicines at the shop when sick. Street children in the Maospati area of Magetan Regency only have their health checked if they are hit by a raid, because some of them almost never have regular health checks. This behavior causes health care that is carried out less than optimal so that there are still many children who do not know how to maintain their health properly. This type of research is quantitative using a cross sectional approach. The sample in this study was street children in the Maospati area, Magetan district, with an average age of 7-16 years, with a sample of 30 respondents and using accidental sampling technique. Data were processed using univariate, bivariate and chi-square methods. The behavior of seeking treatment for street children who received treatment was 14 people (46.7\%) with good health maintenance as many as 13 people $(43.3 \%)$. The behavior of street children who did not take treatment was 16 people $(53.3 \%)$ with less health care as many as 17 people (56.7\%). The results of the Chi Square Test analysis of treatment seeking behavior with street children's health care in the Maospati area of Magetan district obtained a $\mathrm{p}$ value $=0.033$ with a value $=0.05$. Thus Ho is rejected, which means that there is a relationship between Treatment Seeking Behavior and Street Child Health Maintenance in the Maospati Region, Magetan Regency.

Copyright (C) 2021 Eduhealth Journal.All rights reserved. is Licensed under a Creative Commons AttributionNonCommercial 4.0 International License (CC BY-NC
\end{abstract}

4.0)

\section{INTRODUCTION}

Development in the health sector is a very important element in national development, because it is an inseparable part of efforts to improve the quality of human resources [1]. Society or community members in general have different behaviors related to illness and disease. Indonesia is still a developing country and has not been able to solve the problem of poverty[2]. Every human being wants to live a healthy life or at least will maintain the health status he has. Human actions in maintaining health result in the utilization of existing health services, both traditional and modern medicine. However, the relationship between health and demand for health services is not that simple[3]. Utilization of health services is influenced by many factors, not only distance, tariffs and

Relationship Of Treatment-Seeking Behavior With Maintenance Of Street Child Health In Magetan Regency, Nendya Oktavialia 
health services that are satisfactory or not, but are also influenced by the community's concept of illness.[4].

The problem of street children and homeless people is an accumulation of various problems that occur. Starting from poverty, low levels of education, lack of work skills, environment, socioculture, especially health problems[5]. Street children are children who spend most of their time doing activities of daily living on the streets, either to earn a living or roaming the streets and other public places. Doing activities or roaming the streets, the appearance is mostly dull and the clothes are not well cared for and the mobility is high. (Ministry of Social Affairs RI 2005). One of the social problems that are now often encountered and requires serious handling is the problem of street children who are busy in cities or on the roadsides. The lives of street children make them never get formal health services, resulting in health services not being able to reach street children properly and automatically the health level of street children is low.[6]. Street children are considered a problem themselves because apart from disturbing the public, especially at crossroads, stations and terminals, they also unwittingly have problems for themselves, both physically and socially.[7]. Their presence on the road is also a problem for them in relation to their health which is quite vulnerable, among others because of their operation in polluted places such as red light intersections, in the hot sun without sufficient clothing, lack of sanitation facilities for hygiene, not proper for them. looking for a place to rest and so on[8].

Group influence and pressure that causes street children to drink alcohol, smoke and abuse drugs that have an impact on health. As a result of stress, street children are easy to behave antisocially, fight, steal, rob, and extort. There are many cases of rape, sodomy, and other sexual harassment. These problems arise due to lack of knowledge and awareness of the importance of health[9]. In Indonesia cases of neglected children reached 5,900 cases. According to data from the Ministry of Social Affairs, there are 5,900 neglected children (Ministry of Social Affairs, 2015). The number of street children (anjal) continues to increase. Currently in East Java recorded at the Ministry of Social Affairs (Kemensos) reached about 4.1 million. Minister of Social Affairs Khofifah Indar Parawansa said the number of street children increased 100 percent compared to 2015. Last year the number only reached one million people. All of these are accommodated in 6 Child Social Protection Houses (RPSA) throughout Indonesia. According to the Magetan Regency Social Service, the number of street children in the Magetan Regency area is 32 people. From the gathering place for street children, they are located in the Maospati terminal area, Maospati red lights, markets and shelter houses. Most of them become buskers, beggars, scavengers, and sell newspapers. In general, street children are susceptible to infectious diseases, such as ARI, diarrhea, typhoid, hepatitis, and skin as well as prone to nutritional problems[10].

\section{METHOD}

The population in this study were 32 street children in Magetan Regency. The sample in this study were street children in the Maospati terminal area of Magetan district, totaling 24 children, either male or female. Inclusion criteria consisted of street children aged 5-16 years, street children residing in the Magetan Regency area, street children both male and female and willing to be interviewed or answered questionnaires. The exclusion criteria is not willing to be a respondent. The independent variable in this study is the behavior of street children seeking treatment in the Maospati area of Magetan district. The dependent variable in this study is the health care of street children in the Maospati area, Magetan district.

Table 1 Research variables and operational definitions.

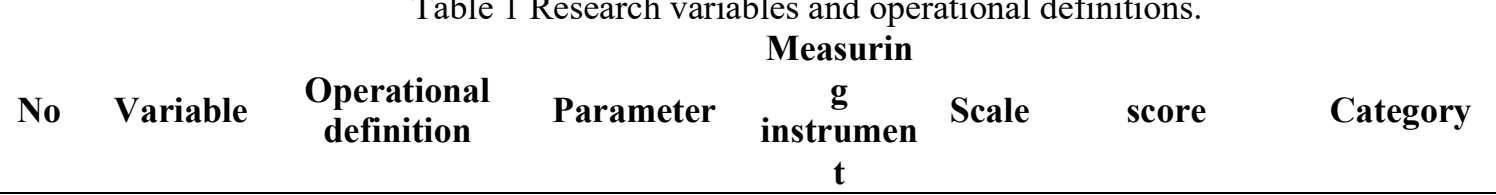




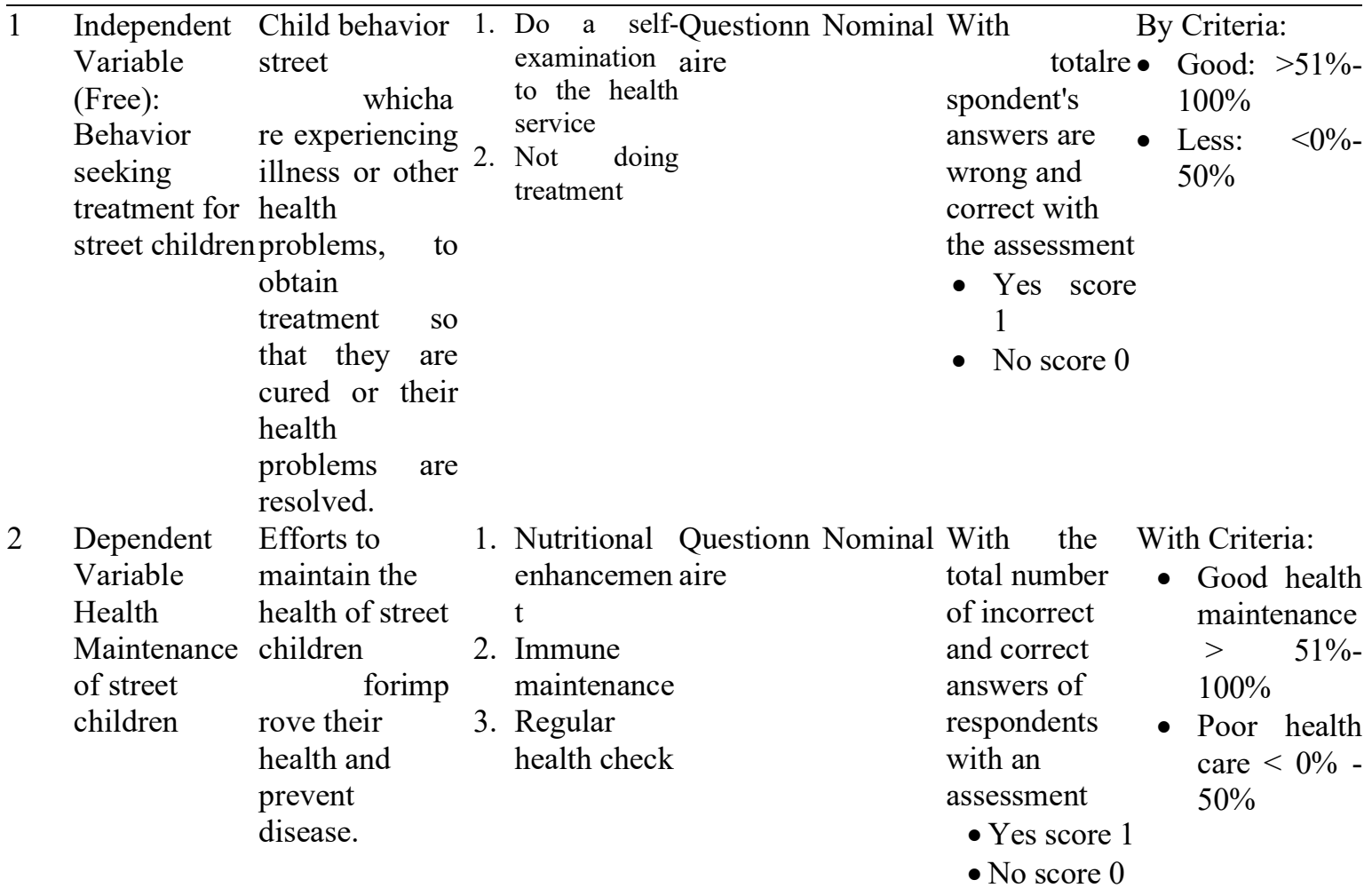

The instrument in this study used a list of questions or questionnaires. The questions used are closed or structured questionnaires where the questionnaire is made in such a way that the respondent only needs to choose or answer the existing ones (respondents only put a mark (x) on the answers provided). The research instrument was then tested for validity and reliability first.

After the questionnaire was tested on the respondents then the correlation was calculated to find out the question of the questionnaire data. Valid or not by using the Product moment correlation formula. The reliability test used in this study is using -Cronbach analysis which can be used well for instruments whose answers are scaled or dichotomous (only recognize two right and wrong answers). The calculation uses -Cronbach reliability, with a reliability coefficient whose numbers are in the range $0-1.00$, the higher the reliability coefficient approaching the number 1.00 , the more reliable it is. Primary data can be obtained from the results of the answers to the questionnaires that have been given to the respondents. Secondary data can be in the form of photo documents, recordings and other documentation.

\subsection{Bivariate Analysis}

General data in the form of demographic data identified from street children in the Maospati area, Magetan Regency, which includes gender, age, education, and occupation.

Table 2. Frequency Distribution by Gender of Respondents Street children in the Maospati area, Magetan Regency

\begin{tabular}{lll}
\multicolumn{1}{c}{ Respondent's Gender } & Amount & Percentage \\
\hline Woman & 12 & 40.0 \\
Man & 18 & 60.0 \\
\hline Total & 30 & 100.0
\end{tabular}

Based on table 2 above, it is known that a small proportion of the sex of the female respondents were 12 people $(40.0 \%)$ and most of the male respondents were 18 people $(60.0 \%)$.

Table 3 Distribution of Frequency Based on Respondent Age Street children in the Maospati area, Magetan Regency.

\begin{tabular}{lll}
\multicolumn{1}{c}{ Respondent's Age } & Amount & Percentage \\
\hline 5-11 yrs & 10 & 33.3 \\
12-16 years old & 20 & 66.7 \\
\hline
\end{tabular}




Total $30 \quad 100.0$

Based on table 3 above, it is known that a small proportion of respondents aged 5-11 years as many as 10 people $(33.3 \%)$ and most of them aged $12-16$ years as many as 20 people $(66.7 \%)$.

Table 4 Distribution of Frequency Based on the education level of street children in the Maospati area, Magetan Regency.

\begin{tabular}{lll}
\multicolumn{1}{c}{ Level of education } & Amount & Percentage \\
\hline SD & 19 & 63.3 \\
junior high school & 11 & 36.7 \\
\hline Total & 30 & 100
\end{tabular}

Based on table 4 above, it is known that a small part of the education level of street children in the Maospati area, Magetan Regency is a junior high school education level of 11 people $(36.7 \%)$ and most of the elementary education level is 19 people $(63.3 \%)$.

Table 5 Distribution of Frequency Based on the occupation of street children respondents in the Maospati area, Magetan Regency

\begin{tabular}{lll}
\multicolumn{1}{c}{ Respondent's Job } & Amount & Percentage \\
\hline busker & 15 & 50.0 \\
Beggar & 10 & 33.3 \\
Scavenger & 5 & 16.7 \\
\hline Total & 30 & 100.0
\end{tabular}

Based on table 5 above, it is known that a small part of the respondents' jobs are scavengers as many as 5 people (16.7\%) and most of the respondents' jobs are buskers as many as 15 people $(50.0 \%)$.

\subsection{Special Data}

Based on table 6 , it can be seen that the respondents with the behavioral level did not take medication as many as 16 people $(53.3 \%)$ and 14 people did treatment $(46.7 \%)$.

Table 6 Distribution of Frequency Based on Treatment Seeking Behavior of Street Children in Maospati Area, Magetan Regency

\begin{tabular}{lll}
\multicolumn{1}{c}{ Behavior } & Amount & Percentage \\
\hline Not Treat & 16 & 53.3 \\
Treat & 14 & 46.7 \\
\hline Total & 30 & 100.0
\end{tabular}

Based on table 7, it can be seen that there are 17 respondents $(56.7 \%)$ with poor health care levels and $13(43.3 \%)$.

Table 7 Distribution of Frequency Based on Street Child Health Maintenance in Maospati Area, Magetan Regency

\begin{tabular}{lll}
\multicolumn{1}{c}{ Health Care } & Amount & Percentage \\
\hline Not enough & 17 & 56.7 \\
Well & 13 & 43.3 \\
\hline Total & 30 & 100.0
\end{tabular}

This study uses a statistical test, namely the Chi_Square test.

Table 8 Cross tabulation based on the relationship between treatment seeking behavior and street children's health care in the Maospati area, Magetan Regency

\begin{tabular}{|c|c|c|c|c|c|c|c|}
\hline \multirow{3}{*}{$\begin{array}{c}\text { Treatment } \\
\text { seeking behavior }\end{array}$} & \multirow{3}{*}{$\begin{array}{c}\text { Not } \\
\text { enough } \\
\text { F }\end{array}$} & \multicolumn{3}{|c|}{ Health Care } & \multirow{2}{*}{\multicolumn{2}{|c|}{ Total }} & \multirow{3}{*}{ P. Value } \\
\hline & & Well & Well & Not & & & \\
\hline & & $\%$ & $\mathbf{F}$ & $\%$ & $\mathbf{F}$ & $\%$ & \\
\hline \multirow{2}{*}{$\begin{array}{l}\text { Not treating } \\
\text { treat }\end{array}$} & 12 & $40.0 \%$ & 4 & $13.3 \%$ & 16 & $53.3 \%$ & \multirow{3}{*}{0.033} \\
\hline & 5 & $16.7 \%$ & 9 & $30.0 \%$ & 14 & $46.7 \%$ & \\
\hline Total & 17 & $56.7 \%$ & 13 & $43.3 \%$ & 30 & 100 & \\
\hline
\end{tabular}

Based on table 8 , the results of the analysis of the relationship between treatment seeking behavior and health care above indicate that based on the chi-square test analysis, the results of the statistical test show the value of $=0.033<=0.05$, thus Ho is rejected which means that there is a 
relationship between behavior Seeking Treatment with Street Child Health Maintenance in Magetan Regency.

\section{RESULTS AND DISCUSSION}

\subsection{Treatment Seeking Behavior of Street Children}

Based on the results of research conducted on 30 respondents, it was found that most of the respondents seeking treatment behavior did not take treatment as many as 16 people $(53.3 \%)$, while a small proportion of treatment seeking behavior by doing treatment as many as 14 people (46.7\%). The behavior of seeking treatment for street children in the Maospati area of Magetan Regency in general is that which is often done by self-medicating, namely by buying medicines at the shop when sick. Only a small proportion of street children who seek treatment at health care facilities. Street children in the Maospati area of Magetan Regency only have their health checked if they are hit by a raid, because some of them almost never have their health checked.

The behavior of seeking treatment for street children in the Magetan district is mostly unfavorable due to the behavior of the street children if they are sick, they do not take treatment for themselves because they think that the pain they feel does not interfere with their activities. And a small number of street children do their own treatment or seek out traditional or modern treatment. Efforts to seek treatment are a description of the behavior of using health services as a whole that can describe the level of knowledge and trust in existing health facilities. There are differences in the search for treatment and there are different ways of thinking about seeking treatment.

Based on the results of the research above, it can be concluded that the behavior of seeking treatment in street children is different, influenced by the lack of knowledge, information, insight and experience in street children who are not good about health.

\subsection{Treatment Seeking Behavior of Street Children}

Based on the results of research conducted on 30 respondents, it was found that most of the health care providers lacked 17 people $(56.7 \%)$ and a small portion of good health care were 13 people $(43.3 \%)$. This shows that there is a lack of effort in maintaining the health of street children on street children.

Health care for street children is generally the same, the main problem is the habit factor in the community that forms lazy behavior to maintain health. Like lazy to take a shower, brush your teeth, wash your hair. Another obstacle is the absence of cleaning tools such as towels, toothbrushes, soap, toothpaste, besides that it is not easy to access toilet facilities. The habit of washing hands before eating is almost not owned by street children.

Based on the results of the research above, it can be concluded that the health maintenance of street children is influenced by unfavorable behavior. This behavior causes health care that is carried out less than optimal so that there are still many children who do not know how to maintain their health. Therefore, knowledge and motivation are needed both from the family environment, and supporting health workers to improve the health status of street children.

\subsection{Discussion}

Based on the research, it was found that based on the cross tabulation between treatment seeking behavior and health care above, it showed that the behavior of street children who treated 14 people $(46.7 \%)$ with good health maintenance was 13 people $(43.3 \%)$. Respondents who did not receive treatment were 16 people $(53.3 \%)$ with less health care as many as 17 people $(56.7 \%)$. Based on the analysis of the chi-square test, it shows that the statistical test results get a value of $=0.033<=$ 0.05 , thus Ho is rejected, which means that there is a relationship between Treatment Seeking Behavior and Street Child Health Maintenance in the Maospati Region, Magetan Regency.

Behavior and health care in street children in the Maospati area of Magetan district is not good due to the environment, knowledge, social status, awareness. The environment for street children is generally a slum environment and has an impact on the health of street children. Knowledge about health is lacking due to lack of socialization to street children from the local office. Awareness about individual health in street children is lacking because they think that illness will heal by itself if only by resting and buying ordinary medicine without going to health services. they feel fear, shame, and cost. Behavior is the result of all kinds of human experiences and interactions with their environment. 
Human behavior tends to be holistic (holistic), and basically consists of psychological, physiological, and social points of view. However, these three points of view are difficult to distinguish between their influence and role on the formation of human behavior. Human behavior is a reflection of various psychological elements that include desires, attitudes, reactions, fear or anxiety, and so on.

Self-medication in a general sense is what ordinary people do to cope with their own pain complaints using drugs, traditional medicines, or other methods without the guidance of health workers. The purpose of self-medication is to improve health, treat minor ailments and routine treatment of chronic diseases after doctor's treatment. The reasons for self-medication are practical in terms of time, trust in traditional medicine, privacy concerns, lower costs, long distances to health services and less satisfaction with health services.

\section{CONCLUSION}

Based on the results of research on the relationship between Treatment Seeking Behavior and Health Maintenance of Street Children in the Maospati Region, Magetan Regency, the following conclusions can be drawn: the behavior of street children who take treatment is 14 people $(46.7 \%)$ with the behavior of street children who do not take treatment as many as 16 people $(53.3 \%)$, good health care for street children as many as 13 people (43.3\%) with less health care as many as 17 people (56.7\%) and there is a relationship between Treatment Seeking Behavior and Health Care for Street Children in the District Magetan is the value of $p$ Value $=0.033<$ value of $a=0.05$ Thus Ho is rejected which means there is a relationship.

\section{REFERENCES}

[1] E. Laing, "PELAKSANAAN PEMBANGUNAN BIDANG KESEHATAN DI KECAMATAN KAYAN SELATAN KABUPATEN MALINAU," J. Adm. Reform, vol. 7, no. 2, 2020, doi: 10.52239/jar.v7i2.3085.

[2] Y. Hasanah, R. M. Dai, and D. S. Sari, "IMPLEMENTASI KEBIJAKAN FUNGSI PUSKESMAS SELAMA SELATAN KABUPATEN BANDUNG," J. Pemikir. dan Penelit. Adm. Sos. Hum. dan Kebijak. Publik, vol. 3, no. 4, 2020.

[3] A. Sjafari, K. S. Nugroho, and A. Arenawati, "Analisis Peningkatan Indeks Pembangunan Bidang Kesehatan di Provinsi Banten," JIPAGS (Journal Indones. Public Adm. Gov. Stud., vol. 4, no. 1, 2020, doi: 10.31506/jipags.v4i1.7793.

[4] R. K. Sari and D. Handayani, "Pemanfaatan Pelayanan Kesehatan pada Anak Indonesia: Pengaruh Kemiskinan dan Karakteristik Ibu," Media Kesehat. Masy. Indones., vol. 16, no. 3, 2020, doi: 10.30597/mkmi.v16i3.9709.

[5] R. P. Puwardi Arifin, Suharyanto Supardi, "Pola Pencarian Pengobatan dan Pemeliharaan Kesehatan Anak Jalanan di Kota Yogyakarta," Manusia dan Lingkungan, vol. X, no. 1. 2003.

[6] W. M. Febriani, "Gambaran Perilaku Pencarian Pengobatan Pada Mahasiswa Fakultas Kesehatan Masyarakat Universitas Airlangga," J. PROMKES, vol. 7, no. 2, 2019, doi: 10.20473/jpk.v7.i2.2019.193-203.

[7] R. Nasriati and R. R. Oktobriani, "Perilaku Keluarga Dalam Pencarian Pengobatan Penderita Gangguan Jiwa (Studi Kasus Di Ponorogo)," Din. Kesehat. J. KEBIDANAN DAN KEPERAWATAN, vol. 10, no. 2, 2019, doi: 10.33859/dksm.v10i2.471.

[8] I. Fila, A. Asrina, and E. Kurnaesih, "Perilaku Pencarian Pengobatan Penyakit Diare pada Balita di Masyarakat Suku Bajo Kabupaten Bone," Patria Artha J. Nurs. Sci., 2019.

[9] N. H. Baharuddin, R. M. Thaha, and A. U. Salamah, "PERILAKU PENCARIAN PENGOBATAN KOMUNITAS WARIA BERISIKO PENYAKIT MENULAR SEKSUAL DI KOTA PALOPO," J. Kesehat. Masy. Marit., vol. 1, no. 3, 2019, doi: 10.30597/jkmm.vli3.8728. 